\title{
Revealing historical fire regimes of the Cumberland Plateau, USA, through remnant fire-scarred shortleaf pines (Pinus echinata Mill.)
}

\author{
Michael C. Stambaugh ${ }^{*}$ (D, Joseph M. Marschall and Erin R. Abadir
}

\begin{abstract}
Background: Vegetation of the Cumberland Plateau (USA) has undergone dramatic transitions since the last glaciation and particularly since the onset of widespread logging and twentieth century fire exclusion. Shortleaf pine (Pinus echinata Mill.), one of the most fire-dependent conifers in the US, occurs throughout the Cumberland Plateau, but its abundance has declined dramatically since Euro-American settlement and continues to decline. To better understand the historical ecology of fire within the natural range of shortleaf pine, we reconstructed fire regimes at three new sites throughout the central and southern Cumberland Plateau region based on fire scars on shortleaf pine trees.
\end{abstract}

Results: Fire event chronologies extended back to the seventeenth century and revealed historical fire regimes that were frequent and dominated by dormant-season and low-severity events. Fires occurred on average every 4.4 to 5.3 years at the study sites before widespread Euro-American settlement, and were more frequent (2.3 to 3.8 years) following settlement. Cumberland Plateau fires may be linked to adjacent ecoregions such as the Eastern Highland Rim to the west. Among all sites, we found that long-term trends in fire activity were similar and fit into a regional waveform pattern of fire activity likely driven by humans (i.e., Native American depopulation, European settlement, and twentieth century fire exclusion).

Conclusions: The decline in shortleaf pine and other fire-dependent ecosystems across the Cumberland Plateau is due to multiple interacting factors and, based on these data, frequent fire should be considered a historically important ecological driver of these systems.

Keywords: anthropogenic fire, fire intervals, fire management, fire scars, Georgia, Kentucky, Tennessee, tree-rings

\footnotetext{
* Correspondence: stambaughm@missouri.edu

Missouri Tree-Ring Laboratory, School of Natural Resources, University of

Missouri, 1111 Rollins Street, Columbia, Missouri 55211, USA
}

\section{Springer Open}

(c) The Author(s). 2020, corrected publication 2020. Open Access This article is licensed under a Creative Commons Attribution 4.0 International License, which permits use, sharing, adaptation, distribution and reproduction in any medium or format, as long as you give appropriate credit to the original author(s) and the source, provide a link to the Creative Commons licence, and indicate if changes were made. The images or other third party material in this article are included in the article's Creative Commons licence, unless indicated otherwise in a credit line to the material. If material is not included in the article's Creative Commons licence and your intended use is not permitted by statutory regulation or exceeds the permitted use, you will need to obtain permission directly from the copyright holder. To view a copy of this licence, visit http://creativecommons.org/ licenses/by/4.0/. 


\section{Resumen}

Antecedentes: La vegetación de la planicie de Cumberland (EEUU) ha sufrido dramáticas transiciones desde la última glaciación y particularmente desde el comienzo de las talas extensivas y la exclusión del fuego en el siglo veinte. El pino de hoja corta (Pinus echinata Mill.), una de las coníferas más dependientes del fuego en los EEUU, se encuentra en toda esta planicie, aunque su abundancia ha declinado dramáticamente desde la colonización euroamericana y continúa haciéndolo. Para entender mejor la ecología del fuego dentro del rango natural del pino de hoja corta, reconstruimos los regímenes de fuego en tres sitios nuevos en el sur y centro de toda la región de la planicie de Cumberland basados en cicatrices de fuego en árboles de este pino.

Resultados: Las cronologías de eventos de fuego se extendieron hacia atrás hasta el siglo diecisiete, y revelaron regímenes de fuego históricos que fueron frecuentes y dominados por eventos ocurridos durante la estación de dormición y de baja severidad. Los fuegos ocurrían en promedio entre 4,4 y 5,3 años en los sitios de estudio antes de la vasta colonización Euroamericana, y fueron más frecuentes (2,3 a 3,8 años) después de la colonización. Los fuegos de la planicie de Cumberland pueden ser ligados a eco-regiones adyacentes como los bordes de tierras altas del Este (Eastern Highland Rim) hacia el oeste. Entre todos los sitios, encontramos que las tendencias a largo plazo en la actividad del fuego fueron similares y encajaban en un patrón de onda regional de actividad del fuego impulsado por humanos (i.e., despoblamiento de aborígenes, colonización de europeos, y exclusión del fuego en el siglo veinte).

Conclusiones: La declinación del pino de hoja corta y otros ecosistemas dependientes del fuego a través de la planicie de Cumberland es debido a múltiples factores interactuantes y, basado en esos datos, la frecuencia del fuego debe ser considerada históricamente como un impulsor ecológico de esos sistemas.

\section{Background}

In an era of widespread fire exclusion and increasing mesophication (Nowacki and Abrams 2008), successful restoration and management of eastern US forest ecosystems requires a robust understanding of the ecological processes that historically shaped them. Fire and silvicultural prescriptions must take into consideration the life history characteristics of desired species and how they interact with local site conditions (e.g., soils, topography, past land use) (Guldin 2007; Dey et al. 2017). Fire history studies of forested stands with remnant individuals of a desirable historically important species can provide the insight needed for effective restoration prescriptions. While fire history studies from fire scars have shown historically frequent fire in several eastern US ecosystems (Guyette et al. 2006a, 2012), such data are lacking across broad regions because of both insufficient spatial coverage of studies and the continuous loss of physical evidence due to decay and disturbances such as logging, agriculture, and burning.

A region where such historical information is needed is the Cumberland Plateau, a broad sandstone-capped uplifted region elongated north to south from Kentucky to northern Alabama, USA (Bailey 1980; Fig. 1). The $53800 \mathrm{~km}^{2}$ Cumberland Plateau is the southern portion of the Appalachian Plateau and lies in the central portion of the Central Hardwoods forest region. Though presently the world's broadest expanse of hardwood-forested plateau (approximately 70\% coverage), Cumberland Plateau vegetation has undergone dramatic changes since the last glaciation, particularly since Euro-American settlement (EAS).

Evidence of fire and human influence on the Cumberland Plateau extends back over 9000 years. Palynological and charcoal records from Cliff Palace Pond in Kentucky show increasing fire activity and a corresponding shift in forest composition towards more fire-tolerant species, including oaks (Quercus L.) and pines (Pinus L.), beginning about 3000 years BP (before present; 1950), and corresponding to the shift from Late Archaic to Woodland culture (Delcourt et al. 1998). Charcoal records from Cliff Palace Pond and across the eastern US have also documented a significant increase in fire activity circa 1800, coincident with EAS (Delcourt and Delcourt 1998). This is consistent with descriptions by early European explorers and settlers, who described vast upland prairies supporting white-tail deer (Odocoileus virginianus Zimmermann), Eastern American elk (Cervus canadensis canadensis Erxleben), and American bison (Bison bison Linnaeus) on the Cumberland Plateau as early as the 1780s (Ramsey 1860). Michaux (1805) attributed the presence of grasslands in the region to fire as early as 1802 . Historical accounts of extensive tarring and turpentining activities and the common use of "pine" in place names provide some evidence that pines (e.g., shortleaf pine, Pinus echinata Mill.; Virginia pine, $P$. virginiana Mill; pitch pine, $P$. rigida Mill.) were once abundant and widespread. Today, however, areas of native grasslands and shortleaf pine have significantly declined across the Cumberland Plateau due to such factors as land conversion, 


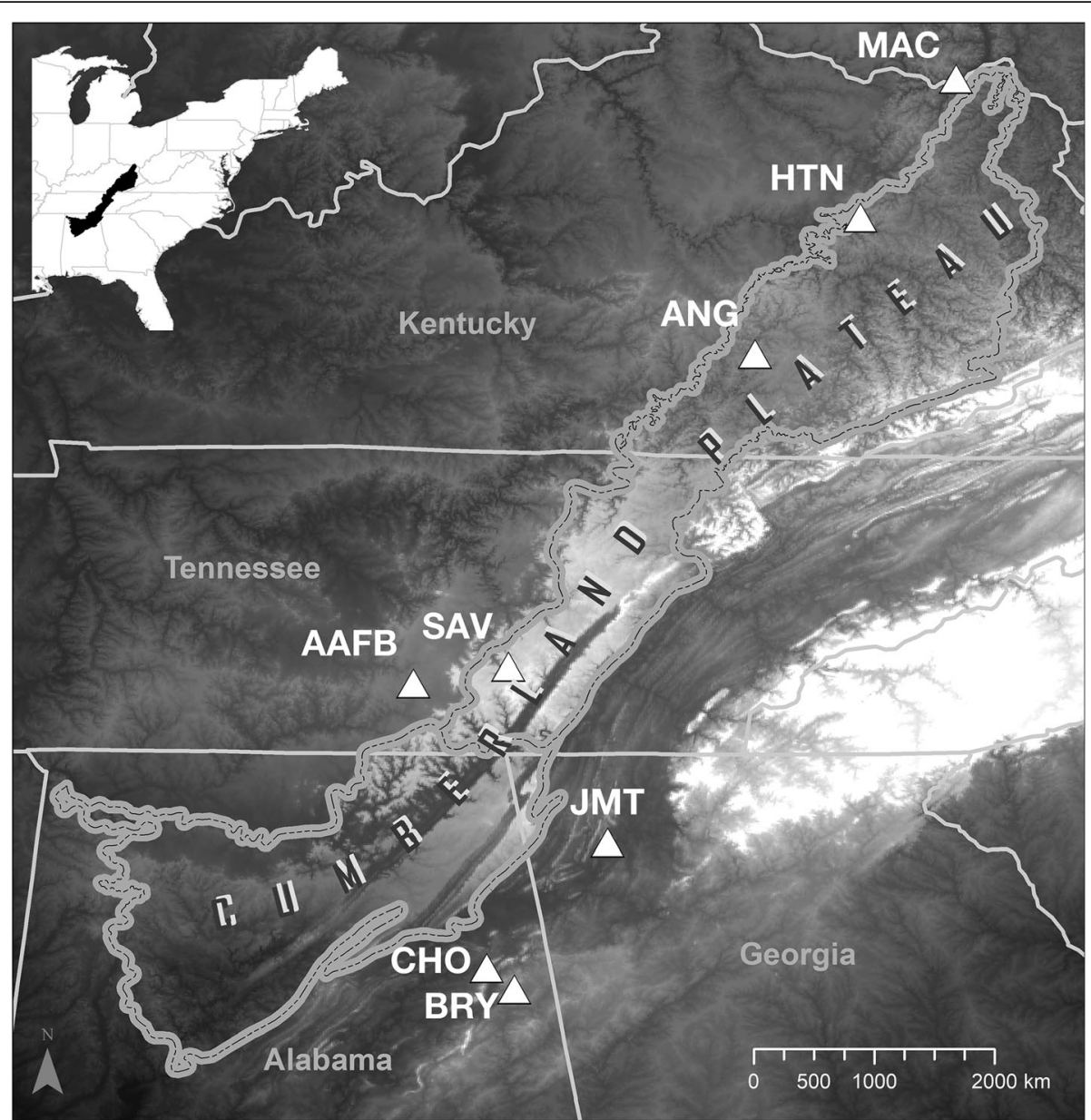

Fig. 1 The Cumberland Plateau ecoregion (bounded by dotted line) with locations of fire-scar history study sites (triangles). Fire scar records developed in this study, between 2017 and 2019, were located at John's Mountain Wildlife Management Area, Georgia (JMT); Angel Hollow, Kentucky (ANG); and Savage Gulf Natural Area, Tennessee (SAV). Other comparable studies in the region are discussed within this paper. To the north, shortleaf pine (Pinus echinata) study sites are located at McAtee Run, Ohio (MAC), and Hatton Ridge, Kentucky (HTN; Hutchinson et al. 2019). To the west, four separate records were developed from post oak (Quercus stellata Wangenh.) woodlands at Arnold Air Force Base, Tennessee (AAFB; Stambaugh et al. 2016) and, to the south, two records of historically very frequent fire exist from montane longleaf pine (Pinus palustris Mill.) in the Appalachian Mountains at Choccolocco Mountain (CHO) and Brymer Mountain (BRY) (Stambaugh et al. 2017)

hardwood succession, loblolly pine (P. taeda L.) plantings, fire exclusion, and outbreaks of southern pine beetle (Dendroctonus frontalis Zimmermann) (South and Harper 2016).

Shortleaf pine is one of the most fire-dependent conifers in the US (Bigelow et al. 2017) and possesses several fire-adapted traits, including the ability to sprout basally from dormant axillary buds at the root collar (Bradley et al. 2016), thick bark, and persistent cones. Shortleaf pine has the broadest natural range of all southern pine species, extending from Connecticut through the southeastern US and westward to the Ouachita Mountains of Oklahoma, including all of the Cumberland Plateau (Lawson 1990). Occupying natural communities ranging from closed canopy forests to open savannas and glades (Nelson 2005), shortleaf pine provides unique vegetation structure and wildlife habitat across vast forest regions that are otherwise dominated by hardwood species (Masters 2007). Recent estimates based on early timber assessments, historical information, and ecological modeling have shown that shortleaf pine forests may have once occupied up to 24 to 28 million hectares across its range (Anderson et al. 2016). Since then, shortleaf pine and shortleaf pine-oak forest types are estimated to have declined at least $90 \%$, occurring on about 2.4 million hectares, with only about $35 \%$ of that occurring east of the Mississippi River (Oswalt 2012).

As management goals in the region increasingly seek to promote and restore diverse and declining ecosystems such as those with shortleaf pine communities, more information is needed about the locations of historical and current habitats, forest stand developmental processes 
for sustainable management (regeneration, growth, and disturbance histories; Hutchinson et al. 2019), and measured responses to specific silvicultural and fire treatments (Harley et al. 2018; Vander Yacht et al. 2018). Currently, only one historical record documenting growth and fire history in a remnant shortleaf pine stand exists at the northern edge of the Cumberland Plateau (Hutchinson et al. 2019). The goal of this work was to increase the body of information describing shortleaf pine sites and fire regimes in the region. Our objectives were to develop fire scar history records in remnant shortleaf pine forests on and adjacent to the Cumberland Plateau, contrast new results to the existing body of work, and attempt to translate these findings to inform modern shortleaf pine management and restoration.

\section{Methods \\ Study sites}

From September 2017 to March 2019, 12 publicly owned lands across the greater Cumberland Plateau ecoregion were surveyed for locations of extant shortleaf pine stands, remnant wood, and their suitability as study sites for dendrochronological (tree-ring) fire history reconstruction. We sought areas with both living and remnant shortleaf pine trees (e.g., stumps, snags, downed logs). Stands were considered appropriate for expanded study when at least 30 suitable remnant trees were identified within a $1 \mathrm{~km}^{2}$ area. Trees were sampled when they exhibited a sufficient number of tree rings for crossdating and fire scars. Limiting the study site area to approximately $1 \mathrm{~km}^{2}$ allowed fire history summaries and statistics to be compared to similar studies throughout the eastern US. The Cumberland Plateau field surveys resulted in the selection of three sites for fire history reconstruction located at Johns Mountain Wildlife Management Area (JMT), Savage Gulf State Natural Area (SAV), and Angel Hollow (ANG) (Fig. 1).

The JMT study site was located in Gordon County, northwestern Georgia (longitude: 34.508 ${ }^{\circ}$ latitude: $\left.-85.065^{\circ}\right)$ in the Conasauga Ranger District of the Chattahoochee-Oconee National Forest and within the 10 056-hectare Johns Mountain Wildlife Area that is managed for multiple uses. The site was on the southern edge of the Cumberland Plateau in the Armuchee Ridges of the Ridge and Valley Province (Smalley 1979). Vegetation primarily consisted of closed-canopy mixed hardwood forests with small inclusions of shortleaf and Virginia pines. Remnant shortleaf pines were sampled on west and east aspects, including ridgetops in between, at elevations between 305 and $425 \mathrm{~m}$. Mean annual minimum and maximum temperatures were $8.3^{\circ} \mathrm{C}$ and $21.1{ }^{\circ} \mathrm{C}$, respectively. Mean annual precipitation was $148.6 \mathrm{~cm}$, with monthly means ranging from 9.3 (Oct) to
$14.2 \mathrm{~cm}$ (Dec; https://www.usclimatedata.com/climate/ la-fayette/georgia/united-states/usga0312).

The SAV site was located in Grundy County in central Tennessee within the Savage Gulf State Natural Area, a part of South Cumberland State Park (longitude: $35.463^{\circ}$; latitude $-85.594^{\circ}$ ). The site is in the MidCumberland Plateau ecoregion and True Plateau subregion (Smalley 1982). Topography consists of a combination of relatively flat plateau, sandstone cliffs, and deeply dissected canyons harboring mixed-mesophytic forests (Quarterman et al. 1972), and oak forests in the uplands (Hart et al. 2012). The study site was located primarily on the top of the Plateau in relatively flat uplands 0 to $1000 \mathrm{~m}$ distant from the rim of the escarpment at an elevation of approximately $580 \mathrm{~m}$. Here, forests were composed of primarily closed-canopy mixed hardwoods transitioning to Virginia and shortleaf pine and dense stands of mountain laurel (Kalmia latifolia L.) along the escarpment rim. Mean annual minimum and maximum temperatures were $6.1{ }^{\circ} \mathrm{C}$ and $18.9^{\circ} \mathrm{C}$, respectively. Mean annual precipitation was $146.5 \mathrm{~cm}$, with monthly means ranging from 9.0 (Oct) to $14.1 \mathrm{~cm}$ (Dec; https://www.usclimatedata.com/climate/coalmont/tennessee/united-states/ustn0644).

The ANG study site was located in Laurel County, Kentucky, within the London Ranger District of Daniel Boone National Forest (longitude: $37.142^{\circ}$; latitude: $\left.-84.262^{\circ}\right)$. The site is within the Mountains and Dissected Plateau Subregion of the Northern Cumberland Plateau ecoregion (Smalley 1986). Topography consists of highly dissected slopes and flat ridges. The study site was primarily on westerly aspects on upper slope positions at elevations between 270 and $290 \mathrm{~m}$. Forests were primarily composed of closed-canopy mixed hardwoods, with areas including Virginia and shortleaf pine along with dense stands of mountain laurel on the shoulder positions with western aspects. Mean annual minimum and maximum temperatures were $7.8{ }^{\circ} \mathrm{C}$ and $19.4{ }^{\circ} \mathrm{C}$, respectively. Mean annual precipitation was $119.7 \mathrm{~cm}$, with monthly means ranging from 7.7 (Oct) to $13.2 \mathrm{~cm}$ (May; https://www. usclimatedata.com/climate/london/kentucky/unitedstates/usky1090).

\section{Sample collection}

At each site, 10 centimeter-thick cross-sections were cut from the base of remnant trees using a chainsaw. Partial cross-sections were cut from living trees to minimize the impact of sampling on living vegetation (Fig. 2). Crosssections were oriented in relation to slope, aspect, and height above ground. Sample locations were recorded using a GPS and photographs were taken to document the field context. Increment cores from five to ten living shortleaf pine trees were also collected at each site to 

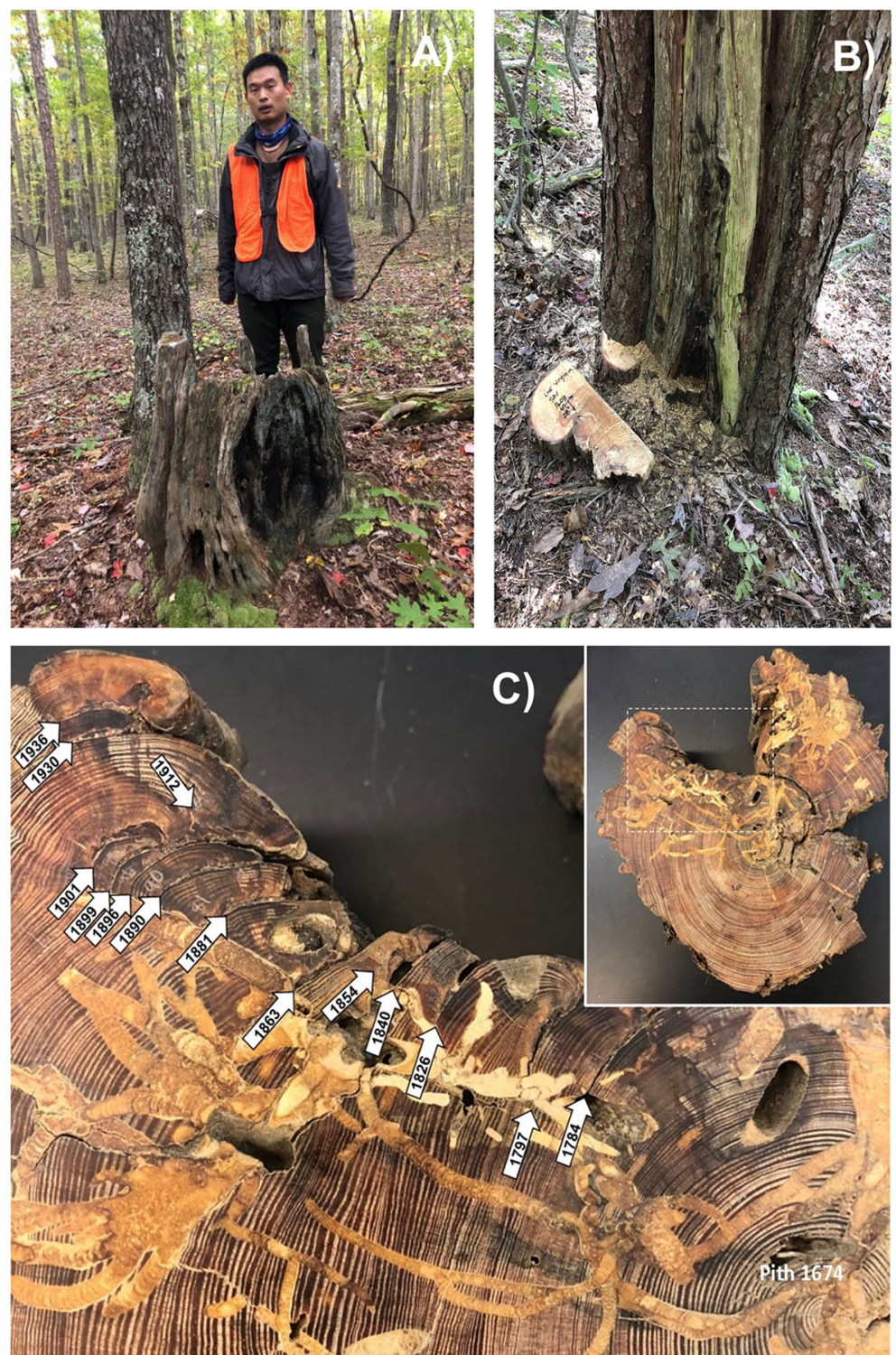

Fig. 2 (A) A fire-scarred stump of a large remnant shortleaf pine (Pinus echinata) tree persists on the Cumberland Plateau, USA, and strongly contrasts with the current conditions of a closed-canopy forest, nearly devoid of living shortleaf pines. (B) Base of living shortleaf pine showing fire scarring on the bole and a partial cross-section with fire scars removed. (C) Shortleaf pine tree-rings and fire scars from the late 1600 s to early 1900s. Calendar years of fire scars are provided within white arrows (inset shows entire sample). Samples were taken between 2017 and 2019 to reconstruct the characteristics of shortleaf pine historical fire regimes. Photographer: Michael Stambaugh

establish a local ring-width chronology to aid in the crossdating of dead remnant tree samples.

\section{Tree-ring measurement and dating}

In the laboratory, samples were dried and then their surfaces were progressively sanded using 80 to 1200 grit sandpaper to reveal cellular detail of tree-rings and firescar injuries. Tree-ring widths were measured in sequence to $0.01 \mathrm{~mm}$ precision using a Velmex TA measuring system (Velmex, Inc., Bloomfield, New York,
USA). Ring-width series were plotted and crossdated using standard dendrochronological techniques (Stokes and Smiley 1968) and verified statistically using the COFECHA computer program (Holmes et al. 1986). Fire scars on cross-sections were identified from the presence of callus tissue, charcoal, barrier zones, and cambial injuries (Fig. 2). Fire-scar injuries were assigned to the year of cambial response to injury and, when possible, seasonality was recorded based on the position of the fire scar within the ring (Kaye and Swetnam 1999). 


\section{Fire history analyses}

The fire history analysis software FHAES version 2.0.2 (Brewer et al. 2016) was used to construct fire-event chronologies and calculate fire intervals and summary statistics for each site. Fire intervals were described using mean fire intervals (MFI) and Weibull median fire intervals (WMI), where appropriate. MFIs are calculated as the average number of years between fire events at a site. For WMIs, we modeled fire-interval distributions using a two-parameter Weibull distribution and tested their fit using a Kolmogorov-Smirnov goodness-offit test. When significant, we reported WMIs as another metric of fire interval. Fire-scar seasonality and the percentage of trees scarred during fire years were also summarized. All statistical analyses were limited to years with at least three trees represented in the tree-ring record.

Data analyses and summaries were calculated for all years of record and also for three sub-periods representing changes in human occupancy and culture: pre-EuroAmerican settlement (pre-EAS), Euro-American settlement (EAS), and Fire Exclusion. While some variation in local history existed among the sites, to facilitate straightforward comparisons we selected the year 1834 as the approximate beginning of significant land use changes due to EAS based on the Indian Removal Act of 1830. The year 1935 was selected as the beginning of effective fire exclusion based on national forest and state park records of early fire suppression activities (Collins 1975, Fearrington 1986).

\section{Additional analysis}

Superposed Epoch Analysis (SEA) was conducted using FHAES to explore possible associations between regional drought conditions and fire occurrence. Reconstructed summer season Palmer Drought Severity Indices (PDSI; grid point 220 for SAV, JMT; grid point 228 for ANG; Cook et al. 2004) were compared to all fire-event years by site, fire-event years synchronous among sites, and fireevent years stratified by sub-periods and percentage of trees scarred to thoroughly explore any potential significant associations. In the SEA, we bootstrapped PDSI data for 1000 simulated events to derive confidence limits that were then used to test whether drought conditions of fireevent years were significantly wetter or drier than expected. To account for potential lagged effects of drought on fire occurrences, SEA tests included the six years preceding and four years succeeding fire events.

To investigate and discuss longer-term regional trends in historical fire activity, we calculated and plotted the number of fires per decade (FPD) over the full period of record using a moving ten-year window. FPD plots were grouped by ecoregion, including: data from study sites to the west of the Cumberland Plateau in the Eastern
Highland Rim (four sites at Arnold Air Force Base [AAFB] located approximately $40 \mathrm{~km}$ southwest of SAV; Stambaugh et al. 2016); study sites to the south in the southern Appalachians Ridge and Valley (Stambaugh et al. 2017); and study sites to the north in the Ohio River Valley (Guyette et al. 2003; Hutchinson et al. 2019) (Fig. 1). Shared fire years across these ecoregions were identified.

\section{Results}

\section{Johns Mountain Wildlife Management Area (JMT)}

Samples of 30 dead and live shortleaf pine trees were collected from an approximately 100 ha area at JMT. Of these, 21 samples were crossdated, spanning the period 1664 to 2017 (354 years; Fig. 3). A total of 131 fire scars were dated, with event years ranging from 1667 to 1948 , and up to 16 fire scars recorded on a single tree. Statistical analyses of fire events were conducted for the period 1673 to 1979 . During the pre-EAS sub-period at JMT (1673 to 1834), fire intervals ranged from 1 to 26 years, the MFI was 5.3 years, and the mean percentage of trees scarred during fire years was $16.1 \%$ (Table 1). All pre-EAS fire scars for which seasonality could be determined $(n=25)$ occurred during the dormant season (i.e., between growth rings). During the latter portion of this sub-period, fire frequency abruptly increased from about 1784, coincident with significant increases in human occupancy of both Cherokee and Euro-Americans (Fig. 3), and fire remained frequent until about 1924.

For the period 1834 to 1935 (EAS), fire intervals ranged from 1 to 6 years with an MFI of 2.3 years and the mean percentage of trees scarred during fire years was $13.2 \%$. The majority of seasonally identifiable fire scars $(n=41,82.9 \%)$ occurred in the dormant season. The 1930 fire year had the highest percentage of trees scarred (70\%) and occurred in the latewood (summer to early fall). Three fire years $(1936,1945,1948)$ were recorded during the fire exclusion period.

\section{Savage Gulf State Natural Area (SAV)}

Samples of 48 dead and live trees were collected from an approximately 270 ha area at Savage Gulf State Natural Area. Of these, 31 were crossdated, spanning the period 1605 to 2018 (413 years; Fig. 4). A total of 144 fire scars were dated, ranging from years 1635 to 1977 , with up to 20 fire scars on a single tree. Statistical analyses of fire events were conducted for the period 1659 to 2018, when at least three trees were represented in the record. During the pre-EAS sub-period at SAV (1659 to 1834), fire intervals ranged from 1 to 21 years, the MFI was 4.4 years, and the mean percentage of trees scarred during fire years was $10.0 \%$ (Table 1$)$. The majority of fire scars for which seasonality could be determined $(n=$ $25,92 \%$ ) occurred during the dormant season (i.e., between growth rings). An early period of annual burning occurred 


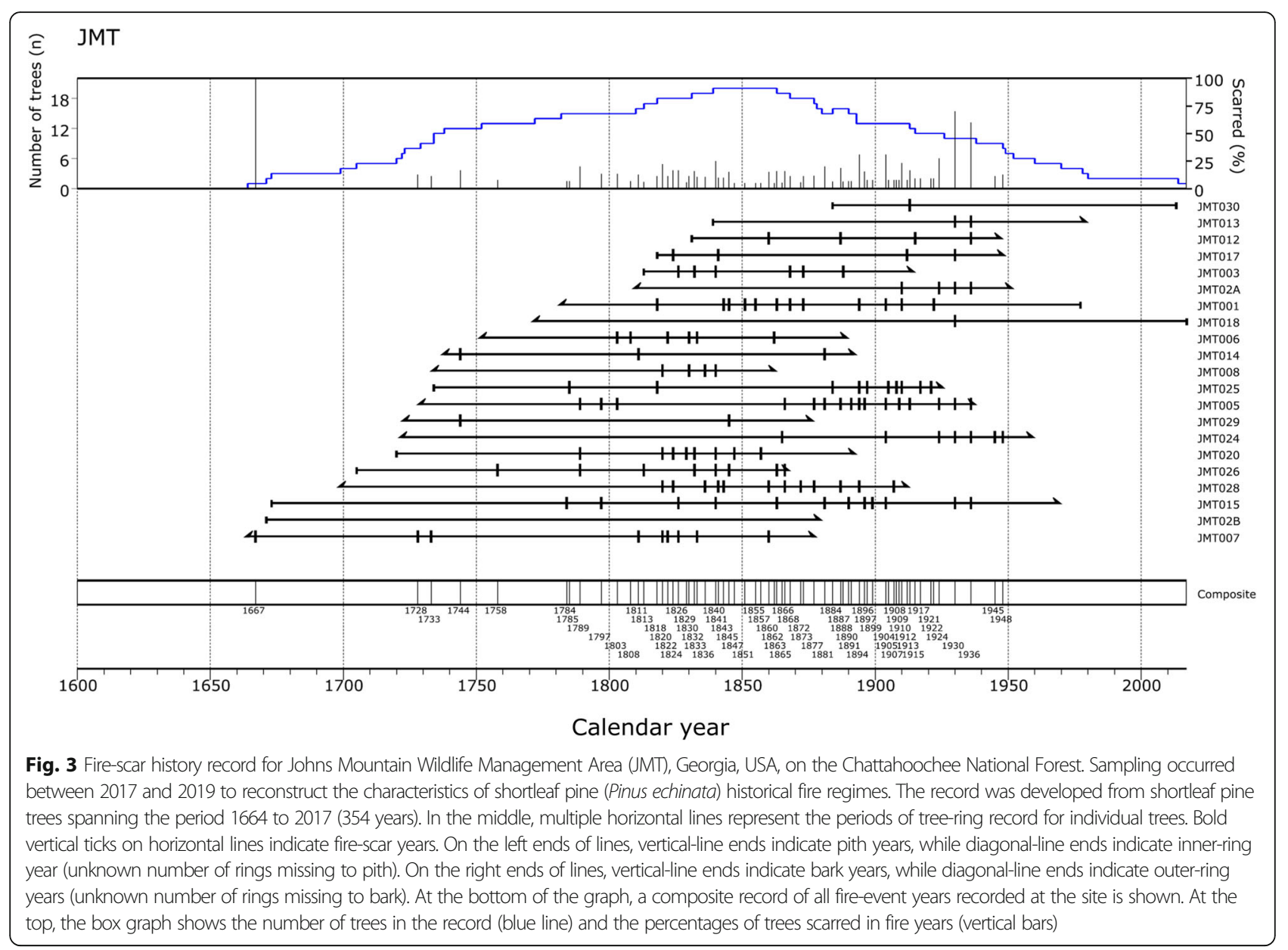

from 1795 to 1798 , and multiple periods of annual burning occurred later during the EAS sub-period.

Coincident with significant increases in Euro-American settlers in the region of SAV, fire frequency increased. For the EAS sub-period (1834 to 1935), fire intervals ranged from 1 to 8 years, the MFI was 2.5 years, and the mean percentage of trees scarred during fire years was $10.6 \%$. The majority of seasonally identifiable fire scars occurred in the dormant season $(n=49,71.4 \%)$. Four fires were recorded following the advent of fire exclusion activities circa 1935, during which fire intervals ranged from 3 to 32 years, the MFI was 13.7 years, and the mean percentage of trees scarred during fire years was $28.2 \%$. Of the fire scars for which seasonality could be determined, $55.6 \%(n=9)$ occurred in the middleearlywood ring position, $22.2 \%(n=2)$ in the late earlywood, and $22.2 \%(n=2)$ in the dormant position. The 1936 fire had the highest percentage of trees scarred (69\%) across the entire record, and scars were located in the middle and late earlywood, suggesting summer timing.

\section{Angel Hollow (ANG)}

Samples of 27 dead and live trees were collected from an approximately 150 ha area at ANG. Twenty-five of these samples were successfully crossdated, spanning the period 1701 to 2017 (317 years; Fig. 5). A total of 98 fire scars were dated, ranging from years 1789 to 1934 . Statistical analyses of fire events were conducted for the period 1740 to 2017. In the time period prior to EAS (1740 to 1834), fire intervals ranged from 2 to 11 years, the MFI was 5.0 years, and the mean percentage of trees scarred during fire years was $18.2 \%$ (Table 1). Of the fire scars for which seasonality could be determined $(n=6), 33.3 \%$ occurred in the dormant ring position, $50 \%$ in the earlywood, and $16.7 \%$ in the late-earlywood portion of the growth ring.

Coincident with increasing local Euro-American settlements in the 1830s, fire frequency increased at ANG. For the period 1834 to 1935 , fire intervals ranged from 1 to 8 years, the MFI was 3.8 years, and the mean percentage of trees scarred during fire years was $16.0 \%$. The majority of seasonally determined fire scars $(n=53,84.9 \%)$ occurred in the dormant season. No fires were recorded following the advent of fire exclusion activities circa 1935 at ANG.

\section{Superposed Epoch Analysis (SEA)}

SEA revealed no significant associations between fire years and drought conditions, including considerations 
Table 1 Fire interval and fire scar seasonality statistics for Johns Mountain Wildlife Management Area, Georgia (JMT); Savage Gulf State Natural Area, Tennessee (SAV); and Angel Hollow, Kentucky (ANG), USA, sampled between 2017 and 2019 to reconstruct the characteristics of shortleaf pine historical fire regimes. Statistics are provided for the full period of record (All years) and sub-periods based on the timing of Euro-American settlement (EAS) and twentieth century fire exclusion. Fires = number of unique fire years, $\mathrm{MFI}=$ mean fire interval, $\mathrm{SD}=$ standard deviation of MFI, Range = range of fire interval length (years), WMI = Weibull median fire interval (years), LEI = lower exceedance interval (95\%; years), UEI = upper exceedance interval (95\%; years), Scarred = mean percentage of trees scarred during fire events (\%), Scars = total number of fire scars, Identified = percentage of fire scars with determinable seasonality, $\mathrm{n} / \mathrm{a}=$ not applicable

\begin{tabular}{|c|c|c|c|c|c|c|c|c|c|c|c|c|}
\hline \multirow[b]{2}{*}{ Site code: } & \multicolumn{3}{|l|}{ All years } & \multicolumn{3}{|l|}{ Pre-EAS } & \multicolumn{3}{|l|}{ EAS } & \multicolumn{3}{|c|}{ Fire exclusion } \\
\hline & JMT & SAV & ANG & JMT & SAV & ANG & JMT & SAV & ANG & JMT & SAV & ANG \\
\hline Time period: & 1673-1979 & 1659-2018 & $1740-2017$ & $1673-1834$ & $1659-1834$ & $1740-1834$ & 1834-1935 & 1834-1935 & 1834-1935 & 1935-1979 & 1935-2018 & 1935-2018 \\
\hline \multicolumn{13}{|c|}{ Fire regime characteristics } \\
\hline Fires $(n)$ & 66 & 66 & 36 & 21 & 23 & 9 & 42 & 40 & 27 & 3 & 4 & 0 \\
\hline MFI (yr) & 3.4 & 3.7 & 4.1 & 5.3 & 4.4 & 5.0 & 2.3 & 2.5 & 3.8 & 6.0 & 13.7 & $\mathrm{n} / \mathrm{a}$ \\
\hline SD (yr) & 3.8 & 4.8 & 2.2 & 6.0 & 4.9 & 2.9 & 1.3 & 1.6 & 1.9 & $\mathrm{n} / \mathrm{a}$ & 16.0 & $\mathrm{n} / \mathrm{a}$ \\
\hline Range (yr) & 1 to 26 & 1 to 32 & 1 to 11 & 1 to 26 & 1 to 21 & 2 to 11 & 1 to 6 & 1 to 8 & 1 to 8 & 3 to 9 & 3 to 32 & $\mathrm{n} / \mathrm{a}$ \\
\hline WMI (yr) & 2.7 & 2.7 & 3.9 & 3.9 & 3.3 & 4.7 & 2.2 & 2.3 & 3.6 & $\mathrm{n} / \mathrm{a}$ & 9.8 & $\mathrm{n} / \mathrm{a}$ \\
\hline LEI (yr) & 0.7 & 0.6 & 1.7 & 0.8 & 0.7 & 2.1 & 0.9 & 0.9 & 1.7 & $\mathrm{n} / \mathrm{a}$ & 2.0 & $\mathrm{n} / \mathrm{a}$ \\
\hline UEI (yr) & 6.7 & 7.5 & 6.7 & 10.7 & 8.9 & 8.2 & 3.8 & 4.4 & 6.1 & $\mathrm{n} / \mathrm{a}$ & 28.1 & $\mathrm{n} / \mathrm{a}$ \\
\hline Scarred (\%) & 13.5 & 11.6 & 16.5 & 16.1 & 10.0 & 18.2 & 13.2 & 10.6 & 16.0 & 27.9 & 28.2 & 0 \\
\hline \multicolumn{13}{|l|}{ Fire scar seasonality } \\
\hline Scars $(n)$ & 130 & 144 & 98 & 40 & 41 & 12 & 82 & 92 & 86 & 8 & 12 & 0 \\
\hline Identified (\%) & 54.2 & 56.8 & 60.2 & 62.5 & 61.0 & 50.0 & 50.0 & 53.3 & 61.6 & 60.0 & 75.0 & $\mathrm{n} / \mathrm{a}$ \\
\hline Dormant & 90.1 & 72.2 & 79.7 & 100.0 & 92.0 & 33.3 & 82.9 & 71.4 & 84.9 & 100.0 & 22.2 & $\mathrm{n} / \mathrm{a}$ \\
\hline Early earlywood & 1.4 & 1.2 & 11.9 & 0.0 & 0.0 & 50.0 & 2.4 & 2.0 & 7.5 & 0.0 & 0.0 & $\mathrm{n} / \mathrm{a}$ \\
\hline Middle earlywood & 0.0 & 20.5 & 0.0 & 0.0 & 8.0 & 0.0 & 0.0 & 20.4 & 0.0 & 0.0 & 55.6 & $\mathrm{n} / \mathrm{a}$ \\
\hline Late earlywood & 1.4 & 2.4 & 3.4 & 0.0 & 0.0 & 16.7 & 2.4 & 0.0 & 1.9 & 0.0 & 22.2 & $\mathrm{n} / \mathrm{a}$ \\
\hline Latewood & 7.0 & 3.6 & 5.1 & 0.0 & 0.0 & 0.0 & 12.2 & 6.1 & 5.7 & 0.0 & 0.0 & $\mathrm{n} / \mathrm{a}$ \\
\hline
\end{tabular}

for lagged effects and filtering fire event years for high percentages of trees scarred. Filtering data to include only fire years that had growing season fire scars yielded the only significant association between fire occurrence and drought conditions. In these cases, conditions were significantly drier than expected the year preceding and year of growing season fire events.

\section{Synchronous fire years}

A total of 121 unique fire years were recorded across the JMT, SAV, and ANG study sites. Of these, 40 fire years (33.1\%) were shared by two of the sites. Five fire years (4.1\%) were recorded at all three sites: 1818, 1829, 1840, 1851, and 1921. All of these years except one (1840) were also recorded at AAFB. The fire year 1829 was also recorded at Hatton Ridge and McAtee Run (see Fig. 1) and corresponded with a drought centered on the lower Ohio River Valley and extending from the Great Plains border in Oklahoma and Kansas eastward, including the Cumberland Plateau (Cook et al. 2010). SEA conducted for the five fire years recorded at all three sites showed a trend towards dry conditions the year before and the year of fires, but was not statistically significant.

\section{Regional fire trends}

Plots of FPD for sites on the Cumberland Plateau showed that similar trends in fire activity existed through time among sites (Fig. 6). The trends followed waveforms characterized as: increased FPD from approximately 1780 to 1820 , stabilized FPD from approximately 1820 to 1910, and then declining FPD from approximately 1910 to 1940 , after which little to no fire activity occurred. For the Cumberland Plateau sites, the maximum fire activity (i.e., FPD) was achieved at a lower level than sites in the southern Appalachians (Fig. 6). Despite JMT being the most southerly site and just outside of the Cumberland Plateau ecoregion boundary, the timing of changes in fire activity along the waveform were later than sites in the southern Appalachians (Choccolocco Mountain [CHO] and Brymer Mountain [BRY]; Fig. 1), and more similar to those of the Cumberland Plateau. 


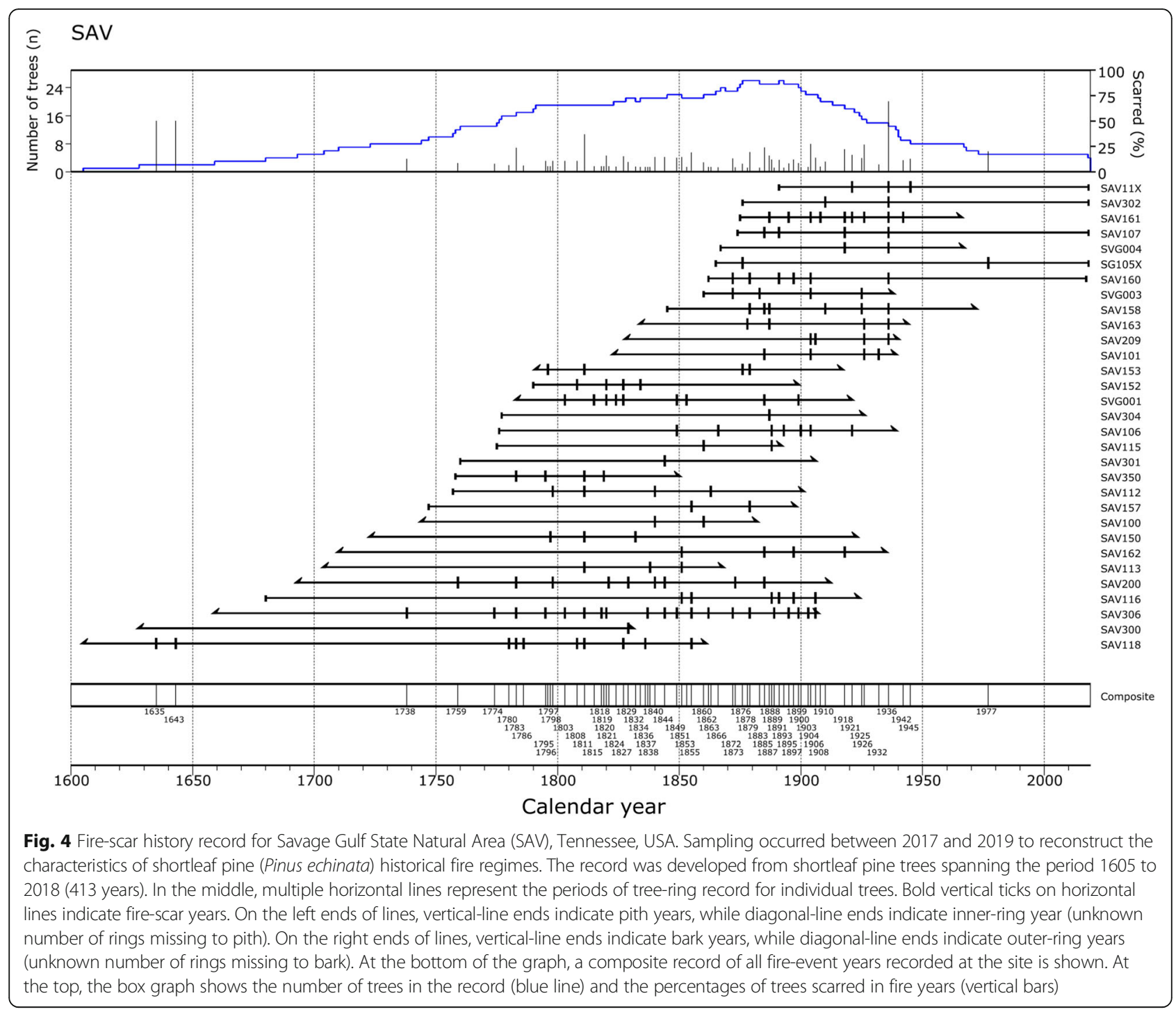

\section{Discussion}

\section{Fire history and shortleaf pine ecology}

Our results provide three new fire scar records documenting historical fire events and regimes across the littlestudied Cumberland Plateau ecoregion. Overall, fire regime characteristics (i.e., frequency, seasonality) were relatively similar among sites despite having different sitelevel event years. Fire frequency varied considerably through time across all sites, with conditions ranging from prolonged periods without fire to prolonged periods of frequent burning and, at times, annual burning. The majority of fires occurred in the dormant season, but some growing-season fires occurred and were associated with drought conditions. Timelines of FPD showed multicentury trends in fire activity that were similar across the Cumberland Plateau and which appear to be evidence of changing anthropogenic influences.
Records of fires at all three study sites began with long periods without fire prior to EAS. From the year in which at least three sample trees were recording at each site, several decades passed before the first fire year at each site. At JMT, this period was 55 years; at SAV, it was 79 years; and at ANG, this period was 49 years. While a lack of fire in early portions of records may be a product of lower sample sizes and spatial coverage, the replication of this effect across the region suggests that the fire hiatus is accurate. Long periods without fire prior to EAS also occurred at the nearest comparable sites at McAtee Run in southern Ohio (Hutchinson et al. 2019) and at Boone Creek Barrens in southern Indiana (Guyette et al. 2003). Decreased fire activity in the centuries prior to EAS may have resulted from either depopulation of Native Americans or cooler climate conditions during the end of the Little Ice Age (Marlon 


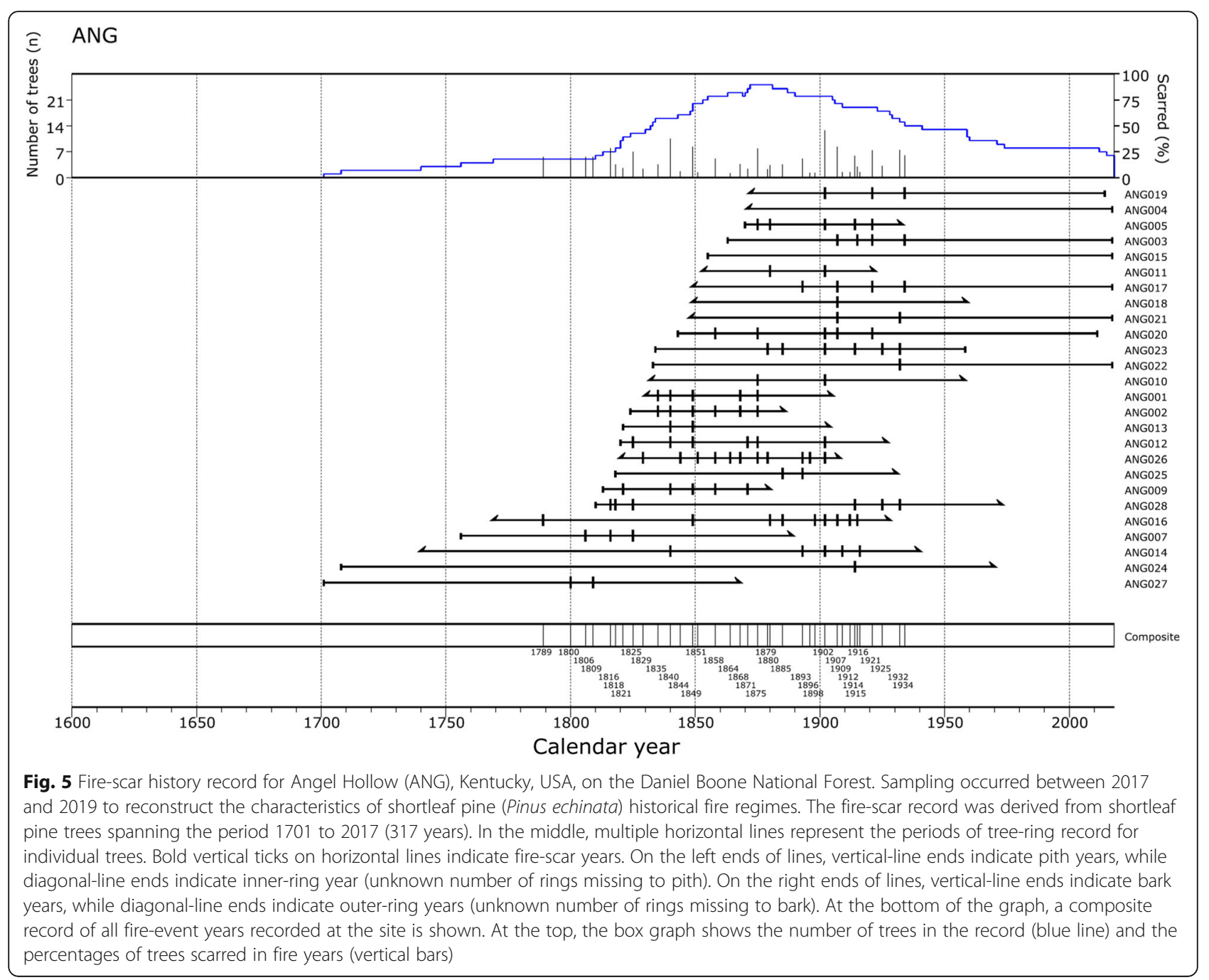

et al. 2008). We suggest that the former is most likely because (1) fire regimes throughout the eastern US have been repeatedly associated with human activity and anthropogenic factors, and (2) study sites in other regions of the eastern US that extend to earlier times show that frequent burning does occur despite conditions of the Little Ice Age (Lafon et al. 2017; Stambaugh et al. 2017, 2018). Thus far, the geography of this fire hiatus appears to cover the Cumberland Plateau and lower Ohio River Valley. Shorter hiatuses occurred in the early 1700s in the Great Lakes region (Muzika et al. 2015; Guyette et al. 2016).

The Pre-EAS MFIs (4.4 to 5.3 years) at the study sites agree with fire regime maps and models that estimate historical MFIs of 5 to 20 years for the Plateau (Frost 1998; Guyette et al. 2012). This frequency of fire is consistent with the expected historical vegetation types and structures based on descriptive accounts of open pine savannas and prairies on the Cumberland Plateau at the time of European settlement. The surveys conducted to locate these study sites revealed that historical shortleaf pine communities and evidence of past fires can be found across the Cumberland Plateau. Old shortleaf pine remnants were located on landscapes ranging from pineoak woodlands on steep, rugged cliffs, to closed-canopy hardwood-dominated forests on gentle terrain.

The fact that many shortleaf pines pre-dated or originated during the era of low fire activity beginning in the mid-1600s suggests that forest conditions were open and fires were relatively frequent prior to this period. Shortleaf pine is highly fire-adapted, and it is unlikely to succeed in closed-canopy forests or regenerate with fire-free periods greater than about 15 years (Stambaugh et al. 2007; Stambaugh and Muzika 2007), especially on the Cumberland Plateau, where site and climate conditions are conducive to forest mesophication in the absence of repeated fire disturbance. An era of frequent fire would have established shortleaf pine and oak as the dominant overstory species at these sites, due to competitive advantages for oak and pine advanced regeneration and limited competitive ability of more mesic species in the 


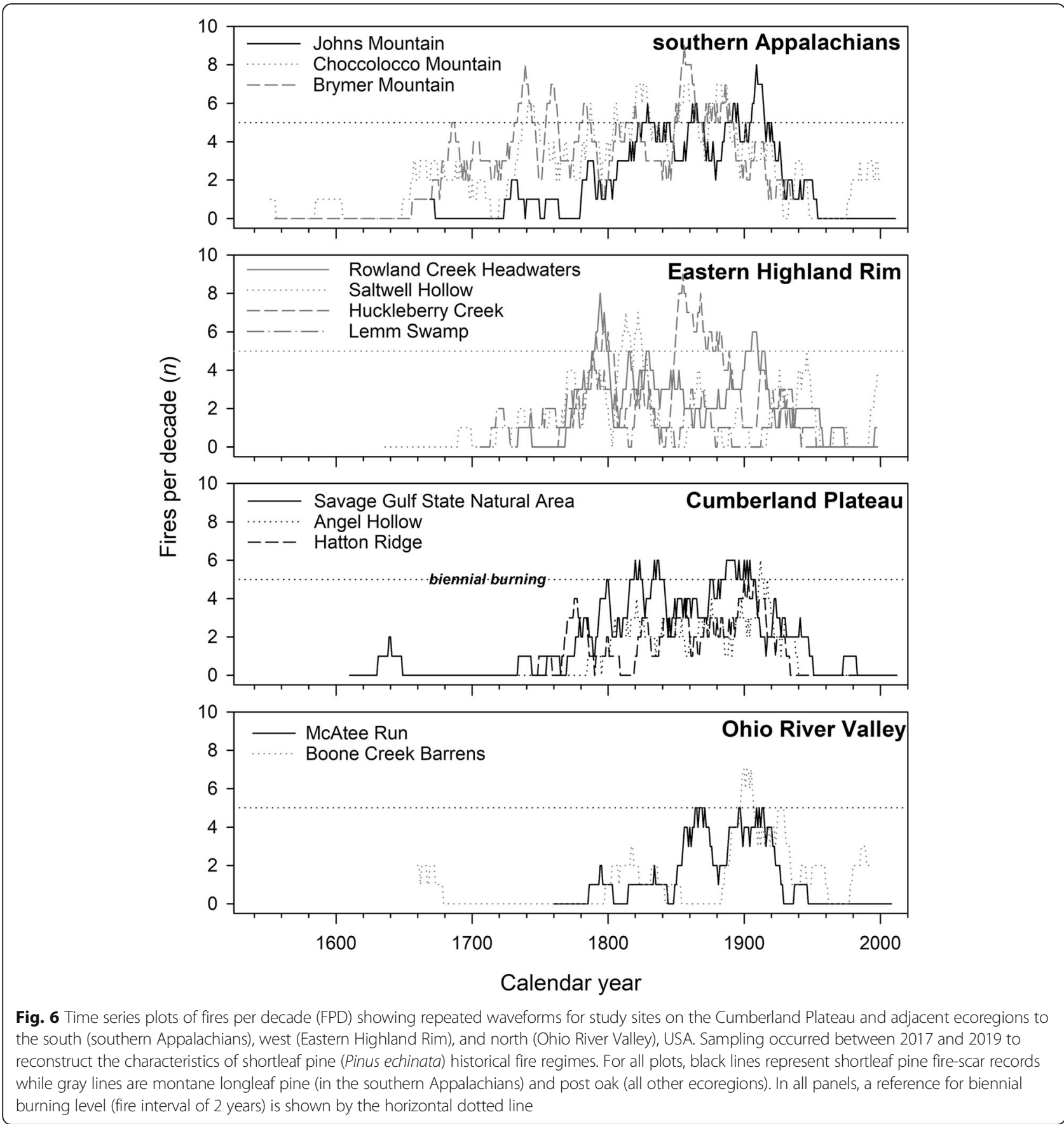

understory (Hanberry et al. 2020). Future fire-scar records that predate those reported here will be of particular value as they will help to better understand the causes and effects of fires in a period of lessened European influence and less-known ecosystem conditions.

Remnant fire-scarred shortleaf pines were prevalent above protected cliffs in areas dominated by rock cover and on sites with shallow soils. In these areas, fuel production is minimal to non-existent and fire occurrences would be expected to be more limited than in uplands where fuels are more continuous and productive. Surprisingly, old fire-scarred trees were found on the tops of $30 \mathrm{~m}$ vertical wall cliffs on the Cumberland Plateau escarpment, on bare rock substrate with minimal adjacent surface fuels. The direction of fire scarring on these trees suggests that these cliffs were not fire breaks and fires moved upslope and over them, likely in conditions conducive to widespread fire (e.g., years of regional drought such as 1829) and ember transport. Similar fire behavior and widespread fires were observed in the 
region during the fall of 2016, when much of the Cumberland Plateau experienced severe to exceptional drought conditions.

Additional evidence for fires moving from below to the top of the Plateau existed below escarpment cliffs at SAV, where very tall $(\sim 5 \mathrm{~m})$ fire scars were observed on remnant pine trees. This suggests that, despite the rugged terrain of the Cumberland Plateau rim, historical fires had the potential to be spatially extensive and linked to fires below (i.e., in the Eastern Highland Rim). On steep, xeric slopes, some of these fires were likely characterized as high or stand-replacement severity. Further sampling that expands spatial coverage of study sites would help to determine how and under what conditions the escarpments and rough topography of the Cumberland Plateau limited fire spread and frequency.

Previous studies at the SAV site provide insight into local topographic controls on historical fire regimes. The site lies just $0.8 \mathrm{~km}$ away from virgin stands of mixedmesophytic forests in the canyon of Savage Creek below (Quarterman et al. 1972) and above the escarpment, adjacent to and partially overlapping sites with old-growth oaks to the east (Hart et al. 2012). The proximity of our site to stands where many fire-sensitive species exist (e.g., American beech, Fagus grandifolia Ehrh.; maple, Acer L. spp.; southern magnolia, Magnolia grandiflora L.; Ohio buckeye, Aesculus glabra Willd.) suggests that microclimate conditions of the canyon below act as a "natural" fire break as it is unlikely that the mixedmesophytic canyon area was protected through active suppression. Although fire was not mentioned in the Quarterman et al. (1972) survey, the presence of some fire-adapted species (e.g., oaks; hickory, Carya Nutt.; Virginia pine) suggests that fire may have had some influence on south-facing slopes.

The historical fire frequencies found at JMT, SAV, and ANG are similar to those documented for shortleaf pine forests in Arkansas, Missouri, and Oklahoma (Guyette et al. 2006b; Stambaugh and Guyette 2008). Similar historical vegetation descriptions exist for these regions as well (Schoolcraft 1821; Swallow 1859). It is possible that fire frequencies may have been more frequent than we have determined through fire scars since low-intensity fires may not always result in cambial injury (fire scars); this is especially possible when fires are frequent over prolonged periods. However, our records do show the ability to detect periods of repeated annual and biennial burning from fire scars, which occurred at all sites (Fig. 6).

Historical fires at the study sites were slightly more frequent than those found in more northern extents of the Cumberland Plateau (Hutchinson et al. 2019) and less frequent than those documented for the southeastern Coastal Plain (Fig. 6). While fire frequency generally decreases with more northerly latitude and lower mean temperatures, this effect may also be due to factors related to humans (e.g., less populated, fewer travel corridors) or landscapes (e.g., proximity to major fire breaks, fire compartment sizes). Conversely, historical fires at the study sites were slightly less frequent than in the Eastern Highland Rim (e.g., similar latitude, $250 \mathrm{~m}$ lower elevation), approximately $40 \mathrm{~km}$ west of SAV.

Comparisons of historical fire years at SAV and sites in the Eastern Highland Rim (AAFB) show the potential for synchronous or linked fires over larger extents. For fires between SAV and AAFB specifically, prevailing westerly winds and upslope directions from the Eastern Highland Rim towards the Cumberland Plateau means that fires could have spread to the Plateau and have some commonality in fire years. Further expansion of sampling fire-scarred trees at new locations within the Savage Gulf landscape would aid in determining the spatial extent of fires beyond a single site (e.g., Marschall et al. 2019) and making more robust linkages to the AAFB sites.

Over multiple centuries, the trend in fire activity of the Cumberland Plateau exhibits a waveform pattern that is repeated, albeit with different timings, at sites in the southern Appalachians, Eastern Highland Rim, and Ohio River Valley (Fig. 6). Repeated waveform patterns in FPD have been previously identified at other sites across the eastern US and were directly analyzed in Pennsylvania (Stambaugh et al. 2018). The FPD waveforms in the Cumberland Plateau (first increases in FPD circa 1780) initiated approximately 60 years later than the earliest settled (eastern-most) sites in Pennsylvania and at a similar timing to the latest settled areas in Pennsylvania.

In Pennsylvania, waveforms in FPD were attributable to changing anthropogenic factors, and this appears to be a plausible explanation for trends in fire activity at the current sites as well. Shifts in human population levels and cultural characteristics can affect ignition rates both negatively (e.g., disease, emigration, fire exclusion policies) and positively (e.g., increased clearing of vegetation, likelihood of unintentional human ignition, warfare). Although many factors can affect anthropogenic fire activity, human population density has repeatedly been shown to be a predictor of long-term fire activity (Guyette et al. 2002; Stambaugh et al. 2013) up until the fire exclusion era.

The lack of a consistent relationship between fire occurrence at the study sites and drought may further reflect the importance of human-fire controls. Studies of fire and drought in the Appalachian region have yielded similar findings (Lafon et al. 2017; McEwan et al. 2007). Anthropogenic fires, compared to lightning fires, include an intelligence factor that allows fires to occur during short dry periods (e.g., weeks) within otherwise wet 
years, obscuring associations between fire occurrence and drought. Fires at the study sites occurred mostly in the dormant season, but growing season fires did occur and may have been extensive in dry years.

The pattern of fire activity through time found at the study sites syncs with observed temporal patterns in tree regeneration. De Graauw and Hessl (2019) found pulses in tree recruitment in the central Appalachians coincident with the regional decline in fire activity, circa 1650 to 1670 , as woody understory vegetation was promoted by the cessation in fire. They also found declining tree recruitment beginning circa 1720 to 1750 onward. We hypothesize that this pattern is due to the increased frequency of fire associated with Euro-American settlement activities, as evidenced on the Cumberland Plateau and many locations across the eastern US (Guyette et al. 2006a).

\section{Conclusions}

Across the Cumberland Plateau exists abundant evidence of historical shortleaf pine communities and frequent-fire regimes. Before widespread Euro-American settlement, fires occurred on average every four to five years at the study sites; following settlement, fires were more frequent and occurred on average every two to four years until the beginning of modern fire exclusion practices. From south to north, fire regimes on the Cumberland Plateau likely follow a minor gradient of decreased fire frequency with southern extents being more like the frequent fire regimes of the Piedmont and Coastal Plain than northernmost areas. Although not detailed here, we located old remnant fire-scarred shortleaf pine wood throughout the Cumberland Plateau, demonstrating the potential for future work towards establishing a more extensive network of firehistory data. These data are needed to address important questions about the characteristics of historical fires, including landscape-scale variability in fire frequency and extent and the importance of humans in perpetuating fireadapted vegetation communities. From a regional perspective, fire-regime data from the Cumberland Plateau and nearby physiographic provinces fill a geographic void between the Appalachians, southeastern Coastal Plain, and western Central Hardwoods (Guyette et al. 2006b; Lafon et al. 2017). Further, these and future data will help to guide fire, forest, and wildlife management decisionmaking needed to sustain fire-dependent species such as shortleaf pine. Interpretation of historical fire ecology of the region should consider historical human influences (e.g., occupation, timing, purpose) and not discount the importance of past and future human fires for ecosystem and societal benefits.

\section{Acknowledgements}

We thank M. Black for logistical and field support in identifying collaborators and locating potential study sites. We especially thank the Chattahoochee National Forest, Tennessee Department of Environment and Conservation, and the Daniel Boone National Forest for permission to conduct research on their lands. Additional acknowledgements to the Tennessee Wildlife Resources Agency for allowing us to access and survey remnant shortleaf pine stands on multiple Wildlife Management Areas. Field context and logistical support for site access was provided by Dr. S. Torreano, R. McCoy, and J. Calvert. Fieldwork support was provided by B. Knapp, H. Du, G. McKee, B. Johnson, A. Vander Yacht, M. Gheesling, and J. Calvert. Laboratory assistance was provided by D. Stelzer and S. Halstead.

\section{Authors' contributions}

MCS: original study design, data collection and curation, statistical analyses, manuscript preparation and editing. JMM: original study design, data collection, laboratory analyses, manuscript editing. ERA: laboratory analyses, statistical analyses, manuscript preparation and editing. The authors read and approved the final manuscript.

\section{Funding}

Funding for this research was provided by the USDA Forest Service,

Southern Research Station, through the University of Tennessee and the Shortleaf Pine Initiative.

\section{Availability of data and materials}

The datasets used or analyzed during the current study will be made available upon reasonable request.

Ethics approval and consent to participate

Not applicable.

Consent for publication

In Figure 2, Dr. Haibo Du consents to his image being shown.

\section{Competing interests}

The authors declare that they have no competing interests.

Received: 23 June 2020 Accepted: 11 September 2020

Published online: 12 October 2020

\section{References}

Anderson, M., L. Hayes, P.D. Keyser, C.M. Lituma, R.D. Sutter, and D. Zollner. 2016. Shortleaf pine restoration plan, $57 \mathrm{https}$ ///www.shortleafpine.net.

Bailey, R.G. 1980. Description of the ecoregions of the United States. U.S. Department of Agriculture Miscellaneous Publication 1391.

Bigelow, S.W., M.C. Stambaugh, A. Larson, and M. Battaglia. 2017. Longleaf pine restoration in context: comparisons among frequent-fire forests. In Ecological restoration and management of longleaf pine forests, ed. K. Kirkman and S. Jack, 311-338. Boca Raton: CRC Press. https://doi.org/10.1201/ 9781315152141-16.

Bradley, J.C., R.E. Will, J.F. Stewart, C.D. Nelson, and J.M. Guldin. 2016. Post-fire resprouting of shortleaf pine is facilitated by a morphological trait but fire eliminates shortleaf $x$ loblolly pine hybrid seedlings. Forest Ecology and Management 379: 146-152. https://doi.org/10.1016/j.foreco.2016.08.016

Brewer, P.W., M.E. Velásquez, E.K. Sutherland, and D.A. Falk. 2016. Fire History Analysis and Exploration System (FHAES) version 2.0.2., [computer software], https://www.fhaes.org. https://doi.org/10.5281/zenodo.34142.

Collins, R.F. 1975. A history of the Daniel Boone National Forest, 1770-1970. U.S. Department of Agriculture, Forest Service, Southern Research Station.

Cook, E.R., D.M. Meko, D.W. Stahle, and M.K. Cleaveland. 2004. North American summer PDSI reconstructions. World Data Center for Paleoclimatology Data Contribution Series \#2004-045. http://www.ncdc.noaa.gov/paleo/newpdsi. html

Cook, E.R., R. Seager, R.R. Heim Jr., R.S. Vose, C. Herweijer, and C. Woodhouse. 2010. Megadroughts in North America: placing IPCC projections of hydroclimatic change in a long-term palaeoclimate context. Journal of Quaternary Science 25: 48-61. https://doi.org/10.1002/jqs.1303.

De Graauw, K.K., and A.E. Hessl. 2019. Do historic log buildings provide evidence of deforestation following depopulation of Indigenous Peoples? Journal of Biogeography 47: 630-642. https://doi.org/10.1111/jbi.13769.

Delcourt, P.A., and H.R. Delcourt. 1998. The influence of prehistoric human-set fires on oak-chestnut forests in the southern Appalachians. Castanea 63: 337345 https://www.jstor.org/stable/4033982. https://doi.org/10.2307/2694697. 
Delcourt, P.A., H.R. Delcourt, C.R. Ison, W.E. Sharp, and K.J. Gremillion. 1998. Prehistoric human use of fire, the Eastern Agricultural Complex, and Appalachian oak chestnut forests: paleoecology of Cliff Palace Pond, Kentucky. American Antiquity 63: 263-278. https://doi.org/10.2307/2694697.

Dey, D.C., J.M. Kabrick, and C.J. Schweitzer. 2017. Silviculture to restore oak savannas and woodlands. Journal of Forestry 115: 202-211. https://doi.org/10. 5849/jof.15-152.

Fearrington, T. 1986. History of the Armuchee Ranger District, 1936-1986. U.S. Department of Agriculture, Forest Service, Armuchee Ranger District, Chattahoochee-Oconee National Forests https://irlibrary.oregonstate.edu/ concern/defaults/tt44pp02k.

Frost, C.C. 1998. Presettlement fire frequency regimes of the United States: a first approximation. In Fire in ecosystem management: shifting the paradigm from suppression to prescription, Tall Timbers Fire Ecology Conference Proceedings No. 20, ed. T.L. Pruden and L.A. Brennan, 70-81. Tallahasee: Tall Timbers Research Station.

Guldin, J.M. 2007. Restoration and management of shortleaf pine in pure and mixed stands--science, empirical observation, and the wishful application of generalities. In Shortleaf pine restoration and ecology in the Ozarks: proceedings of a symposium, ed. J.M. Kabrick, D.C. Dey, and D. Gwaze, 47-58. Newtown Square: U.S. Department of Agriculture Forest Service GTR-NRS-P-15.

Guyette, R.P., D.C. Dey, and M.C. Stambaugh. 2003. Fire and human history of a barren-forest mosaic in southern Indiana. The American Midland Naturalist 149: 21-34. https://doi.org/10.1674/0003-0031 (2003) 149[0021:FAHHOA]2.0.CO;2.

Guyette, R.P., D.C. Dey, M.C. Stambaugh, and R.M. Muzika. 2006a. Fire scars reveal variability and dynamics of eastern fire regimes. In Fire in eastern oak forests: delivering science to land managers, proceedings of a conference, ed. M.B. Dickinson. Newtown Square: U.S. Department of Agriculture, Forest Service GTR-NRS-P-1.

Guyette, R.P., R.M. Muzika, and D.C. Dey. 2002. Dynamics of an anthropogenic fire regime. Ecosystems 5: 472-486 https://www.jstor.org/stable/3658900.

Guyette, R.P., M.A. Spetich, and M.C. Stambaugh. 2006b. Historic fire regime dynamics and forcing factors in the Boston Mountains, Arkansas, USA. Forest Ecology and Management 234: 293-304. https:/doi.org/10.1016/j.foreco.2006.07.016.

Guyette, R.P., M.C. Stambaugh, D.C. Dey, J.M. Marschall, J. Saunders, and J. Lampereur. 2016. 350 years of fire-climate-human interactions in a Great Lakes sandy outwash plain. Forests 189. https://doi.org/10.3390/f7090189, https://doi.org/10.3390/f7090189.

Guyette, R.P., M.C. Stambaugh, D.C. Dey, and R.-M. Muzika. 2012. Predicting fire frequency with chemistry and climate. Ecosystems 15: 322-335. https://doi. org/10.1007/s10021-011-9512-0.

Hanberry, B.B., M.D. Abrams, M.A. Arthur, and J.M. Varner. 2020. Reviewing fire, climate, deer, and foundation species as drivers of historically open oak and pine forests and transition to closed forests. Frontiers in Forests and Global Change. https://doi.org/10.3389/ffgc.2020.00056.

Harley, G.L., C.H. Baisan, P.M. Brown, H.D. Grissino-Mayer, D.A. Falk, W.T. Flatley, A. Hessl, E.K. Heyerdahl, M.W. Kaye, C.W. Lafon, E.Q. Margolis, R.S. Maxwell, A.T. Naito, W.J. Platt, M.T. Rother, T. Saladyga, R.L. Sherriff, L.A. Stachowiak, M.C. Stambaugh, E.K. Sutherland, and A.H. Taylor. 2018. Advancing Dendrochronological Studies of Fire in the United States. Fire 1: 11. https:// doi.org/10.3390/fire1010011.

Hart, J.L., S.L. Clark, S.J. Torreano, and M.L. Buchanan. 2012. Composition, structure, and dendroecology of an old-growth Quercus forest on the tablelands of the Cumberland Plateau, USA. Forest Ecology and Management 266: 11-24 https://doi.org/10.1016/j.foreco.2011.11.001.

Holmes, R.L., R.K. Adams, and H.C. Fritts. 1986. Tree-ring chronologies of Western North Americas: California, Eastern Oregon and northern Great Basin with procedures used in the chronology development work including user's manuals for computer programs COFECHA and ARSTAN, Chronology Series VI. Tucson: University of Arizona, Laboratory of Tree-Ring Research.

Hutchinson, T.F., M.C. Stambaugh, J.M. Marschall, and R.P. Guyette. 2019. Historical fire in the Appalachian Plateau of Ohio and Kentucky, USA, from remnant yellow pines. Fire Ecology 15: 33. https://doi.org/10.1186/ s42408-019-0052-X.

Kaye, M.W., and T.W. Swetnam. 1999. An assessment of fire, climate, and Apache history in the Sacramento Mountains, New Mexico. Physical Geography 20: 305-330. https://doi.org/10.1080/02723646.1999.10642681.

Lafon, C.W., A.T. Naito, H.D. Grissino-Mayer, S.P. Horn, and T.A. Waldrop. 2017. Fire history of the Appalachian region: a review and synthesis. Asheville: U.S. Department of Agriculture Forest Service, GTR-SRS-219.

Lawson, E.R. 1990. Shortleaf pine. In Silvics of North America: 1. Conifers, Vol 1, 316-326. Washington, D.C: U.S.D.A. Forest Service, Agriculture Handbook 654.
Marlon, J.R., P.J. Bartlein, C. Carcaillet, D.G. Gavin, S.P. Harrison, P.E. Higuera, F. Joos, M.J. Power, and I.C. Prentice. 2008. Climate and human influences on global biomass burning over the past two millennia. Nature Geoscience 10: 697-702. https://doi.org/10.1038/ngeo313.

Marschall, J.M., M.C. Stambaugh, B.C. Jones, and E.R. Abadir. 2019. Spatial variability of historical fires across a red pine-oak landscape, Pennsylvania, USA. Ecosphere 10: e02978. https://doi.org/10.1002/ecs2.2978.

Masters, R.E. 2007. The importance of shortleaf pine for wildlife and diversity in mixed oak-pine forests and in pine-grassland woodlands. In Shortleaf pine restoration and ecology in the Ozarks: proceedings of a symposium, ed. J.M. Kabrick, D.C. Dey, and D. Gwaze, 35-46. Newtown Square: U.S. Department of Agriculture Forest Service GTR-NRS-P-15.

McEwan, R.W., T.F. Hutchinson, R.P. Long, R.D. Ford, and B.C. McCarthy. 2007. Temporal and spatial patterns in fire occurrence during the establishment of mixed-oak forests in eastern North America. Journal of Vegetation Science 18: 655-664. https://doi.org/10.1111/j.1654-1103.2007.tb02579.x.

Michaux, F.A. 1805. Travels to the Westward of the Allegheny Mountains, in the States of Ohio, Kentucky, and Tennessee, in the Year 1802. London: Richard Phillips.

Muzika, R.-M., R.P. Guyette, M.C. Stambaugh, and J.M. Marschall. 2015. Fire, drought, and humans in a heterogeneous Lake Superior landscape. Journal of Sustainable Forestry 34: 49-70. https://doi.org/10.1080/10549811.2014. 973991.

Nelson, P.W. 2005. The terrestrial natural communities of Missouri. Jefferson City: Missouri Natural Areas Committee.

Nowacki, G.J., and M.D. Abrams. 2008. The demise of fire and "mesophication" of forests in the eastern United States. Bioscience 58: 123-138. https://doi.org/ 10.1641/B580207.

Oswalt, C.M. 2012. Spatial and temporal trends of the shortleaf pine resource in the eastern United States. In Proceedings of the shortleaf pine conference: east meets west, bridging the gap with research and education across the range, ed. J. Kush, R.J. Barlow, and J.C. Gilbert, 33-37 Special Report, Alabama Agricultural Experiment Station.

Quarterman, E., B.H. Turner, and T.E. Hemmerly. 1972. Analysis of virgin mixed mesophytic forests in Savage Gulf, Tennessee. Bulletin of the Torrey Botanical Club 99: 228-232. https://doi.org/10.2307/2484607.

Ramsey, J.G.M. 1860. The annals of Tennessee. Philadelphia: Lippincott.

Schoolcraft, H.R. 1821. Journal of a tour into the interior of Missouri and Arkansaw. London: Sir Richard Phillips and Co.

Smalley, G.W. 1979. Classification and evaluation of forest sites on the southern Cumberland Plateau. New Orleans: U.S. Department of Agriculture, Forest Service, Southern Forest Experiment Station GTR-SO-23.

Smalley, G.W. 1982. Classification and evaluation for forest sites on the MidCumberland Plateau. New Orleans: U.S. Department of Agriculture, Forest Service, Southern Forest Experiment Station GTR-SO-38. https://doi.org/10. 2737/SO-GTR-38.

Smalley, G.W. 1986. Classification and evaluation for forest sites on the Northern Cumberland Plateau. New Orleans: U.S. Department of Agriculture, Forest Service, Southern Forest Experiment Station GTR-SO-60. https://doi.org/10. 2737/SO-GTR-60.

South, D.B., and R.A. Harper. 2016. A decline in timberland continues for several southern yellow pines. Journal of Forestry 114: 116-124. https://doi.org/10. 5849/jof.15-006.

Stambaugh, M.C., and R.P. Guyette. 2008. Predicting spatio-temporal variability in fire return intervals using a topographic roughness index. Forest Ecology and Management 254: 463-473. https://doi.org/10.1016/j.foreco.2007.08.029.

Stambaugh, M.C., R.P. Guyette, and D.C. Dey. 2007. What fire frequency is appropriate for shortleaf pine regeneration and survival? In Shortleaf pine restoration and ecology in the Ozarks: proceedings of a symposium, ed. J.M. Kabrick, D.C. Dey, and D. Gwaze, 121-128. Newtown Square: U.S. Department of Agriculture, Forest Service, GTR-NRS-P-15.

Stambaugh, M.C., R.P. Guyette, and J.M. Marschall. 2013. Fire history in the Cherokee Nation of Oklahoma. Human Ecology 41: 749-758. https://doi.org/ 10.1007/s10745-013-9571-2.

Stambaugh, M.C., R.P. Guyette, J.M. Marschall, and D.C. Dey. 2016. Scale dependence of oak woodland historical fire intervals: contrasting The Barrens of Tennessee and Cross Timbers of Oklahoma, USA. Fire Ecology 12: 65-84. https://doi.org/10.4996/fireecology.1202065.

Stambaugh, M.C., J.M. Marschall, E.R. Abadir, B.C. Jones, P.H. Brose, D.C. Dey, and R.P. Guyette. 2018. Wave of fire: an anthropogenic signal in historical fire regimes across central Pennsylvania, USA. Ecosphere 9: e02222. https://doi. org/10.1002/ecs2.2222. 
Stambaugh, M.C., and R.-M. Muzika. 2007. Successional trends of six mature shortleaf pine forests in Missouri. In Shortleaf pine restoration and ecology in the Ozarks: proceedings of a symposium, ed. J.M. Kabrick, D.C. Dey, and D. Gwaze, 59-67. Newtown Square: U.S. Department of Agriculture, Forest Service GTR-NRS-P-15.

Stambaugh, M.C., J.M. Varner, and S.T. Jackson. 2017. Biogeography: an interweave of climate, fire, and humans. In Ecological Restoration and Management of Longleaf Pine Forests, ed. K. Kirkman and S. Jack, 17-38. Boca Raton: CRC Press. https://doi.org/10.1201/9781315152141-2.

Stokes, M.A., and T.L. Smiley. 1968. Introduction to tree-ring dating. Chicago: University of Chicago Press.

Swallow, G.C. 1859. Geological report of the country along the line of the southwestern branch of the Pacific Railroad, State of Missouri. St. Louis: George Knapp \& Co.

Vander Yacht, A.L., P.D. Keyser, S.A. Barrioz, C. Kwit, M.C. Stambaugh, W.K Clatterbuck, and D.M. Simon. 2018. Reversing mesophication effects on understory woody vegetation in mid-southern oak forests. Forest Science. https://doi.org/10.1093/forsci/fxy053.

\section{Publisher's Note}

Springer Nature remains neutral with regard to jurisdictional claims in published maps and institutional affiliations.

\section{Submit your manuscript to a SpringerOpen ${ }^{\circ}$ journal and benefit from:}

- Convenient online submission

- Rigorous peer review

- Open access: articles freely available online

- High visibility within the field

- Retaining the copyright to your article

Submit your next manuscript at $\boldsymbol{\nabla}$ springeropen.com 